\title{
Candida utilis metabolism and morphology under increased air pressure up to 12 bar
}

\author{
Rita Pinheiro ${ }^{\mathrm{a}, \mathrm{b}}$, Marlene Lopes ${ }^{\mathrm{a}}$, Isabel Belo ${ }^{\mathrm{a}}$, Manuel Mota ${ }^{\mathrm{a}, *}$ \\ a IBB-Institute for Biotechnology and Bioengineering, Centre of Biological Engineering, University of Minho, Campus de Gualtar, 4710-057 Braga, Portugal \\ ${ }^{\mathrm{b}}$ Escola Superior de Tecnologia e Gestão, Instituto Politécnico de Viana do Castelo, Avenida do Atlântico, Apartado 574, 4900-348 Viana do Castelo, Portugal
}

\section{A R T I C L E I $\quad$ N F}

\section{Article history:}

Received 25 October 2013

Received in revised form

19 November 2013

Accepted 28 November 2013

Available online 4 December 2013

\section{Keywords:}

Candida utilis

Air pressure

Fed-batch culture

Morphology

Ethanol formation

\begin{abstract}
A B S T R A C T
Batch cultures of Candida utilis CBS 621 were carried out in a pressurized reactor under increased air pressure up to 6 bar. The effect of total air pressure was also investigated in a high cell density fed-batch culture, raising the total air pressure from 1 bar to 12 bar. The results showed that the rise of air pressure, for both operation modes, led to a substantial enhancement of biomass production. Moreover, ethanol formation was significantly reduced at 6 bar and 12 bar air pressure, respectively for batch and fed-batch processes.

A method using automatic image analysis for classification of $C$. utilis cells based on their morphology was developed and applied to experimental data. Morphological parameters such as single and budding cells, cell size and elongation factor, were analyzed to assess the pressure effect on yeast culture. No significant differences were observed in cell size distribution and yeast cells retained the typical oval form, even at 12 bar air pressure.

In what biological aspects are concerned, it is possible to state that C. utilis CBS 621 can cope with hyperbaric stress, meaning that the use of increased air pressure is a suitable method for oxygenation enhancement of high-density cultures of this strain.
\end{abstract}

(C) 2013 Elsevier Ltd. All rights reserved.

\section{Introduction}

Candida utilis (fodder yeast) is a popular microorganism for physiological studies on sugar metabolism in yeasts, and it stands as a model for the group of Crabtree-negative yeasts that can exhibit active glucose transport [1]. C. utilis presents high respiratory activity, high protein content, good amino acids profile and ability to utilize a wide range of substrates [2-4]. Furthermore, the predominantly aerobic metabolism of $C$. utilis and active participation of the pentose phosphate pathway for sugar metabolism predisposes this yeast to carbon balance in favor of biomass production when compared to other yeasts as Saccharomyces cerevisiae, which is glucose sensitive and largely fermentative [5].

It is known that the commercial value of single cell protein (SCP) is linked to its protein content. From this point of view S. cerevisiae and a few other yeasts like $C$. utilis are classified among the most interesting microorganisms for their protein content, which can account for up $50 \%$ of the dry weight, being the remaining represented by lipids, polysaccharides, etc. [6,7]. Recombinant C. utilis strains have also been used for heterologous protein expression

\footnotetext{
* Corresponding author. Tel.: +351253 604405; fax: +351253604429.

E-mail addresses: mmota@deb.uminho.pt, marlenelopes@deb.uminho.pt (M. Mota)
}

$[8,9]$ and for production of biotin, ethanol, and lactate [10-12]. In most cases, high cell density cultures (HCDC) of C. utilis are crucial to increase economical productivities. Thus, limiting factors to HCDC need to be taken into account. These include substrate inhibition, oxygen and heat-transfer limitation, accumulation of cellular byproducts such as ethanol, acetic and pyruvic acids and inhibition of cellular respiration by a high concentration of dissolved carbon dioxide [13].

Numerous techniques have been designed to increase cell concentration in aerobic cultures. Most techniques have focused on the control of nutrient and oxygen supplies as a mean to regulate the specific growth rate [14]. Also, de la Torre [15] has proposed the use of continuous cultures with a highly concentrated feed of substrate, at a low dilution rate as a feasible alternative. Since in HCDC oxygen is usually the major growth limiting factor, the use of pressure to improve oxygen transfer rate into bioreactors is an alternative way of preventing oxygen limitation that may reduce operating cost constrains compared to high power input [16]. In fact, previous work demonstrated that hyperbaric air could be successfully applied to fed-batch cultivation of S. cerevisiae [17] and Pichia pastoris [18], to improve oxygen transfer rate to aerobic cultures. However, above certain limits increased air pressure and the consequent raise on oxygen partial pressure have detrimental effects on yeast cell activity. It was proven that oxygen toxicity, besides total pressure, is the main cause of cell inhibition $[19,20]$. 
Some of the cellular response to stressful conditions such as the ones caused by increased air and oxygen pressure are morphological changes $[21,22]$. Computer image analysis for automatic evaluation of microscopic images has been proven as a reliable technique to study the morphological cell changes under increased air pressure [22].

The aim of this work is to analyze the applicability of bioreactor pressurization up to 12 bar air to improve biomass productivity of $C$. utilis. Besides cellular growth and metabolites production assessment under increased pressure, morphological cellular characterization was performed by a developed image analysis procedure [22].

\section{Materials and methods}

\subsection{Strain and maintenance}

C. utilis CBS 621 was obtained from the Centraalbureau voor Schimmelcultures (Delft, The Netherlands). This strain was stored at $-80^{\circ} \mathrm{C}$ with $20 \%(\mathrm{v} / \mathrm{v})$ glycerol. From these stock cultures, agar slants $[2 \%(\mathrm{w} / \mathrm{v})]$ were inoculated and maintained at $4{ }^{\circ} \mathrm{C}$.

\subsection{Media}

The mineral medium for batch experiments consisted in: $5.0 \mathrm{~g}$ $\mathrm{KH}_{2} \mathrm{PO}_{4}, 1.2 \mathrm{~g}\left(\mathrm{NH}_{4}\right)_{2} \mathrm{SO}_{4}, 0.4 \mathrm{~g} \mathrm{MgSO}_{4} \cdot 7 \mathrm{H}_{2} \mathrm{O}, 1.0 \mathrm{~g}$ yeast extract and $40 \mathrm{~g}$ sucrose in $1 \mathrm{~L}$ of citrate buffer $0.1 \mathrm{M}, \mathrm{pH}$ 5.0. The mineral medium for fed-batch experiments consisted in: $7.5 \mathrm{~g} \mathrm{KH}_{2} \mathrm{PO}_{4}, 5.0 \mathrm{~g}$ $\left(\mathrm{NH}_{4}\right)_{2} \mathrm{SO}_{4}, 1.0 \mathrm{~g} \mathrm{MgSO}_{4} \cdot 7 \mathrm{H}_{2} \mathrm{O}, 5.0 \mathrm{~g}$ yeast extract and $100 \mathrm{~g}$ sucrose in $1 \mathrm{~L}$ of citrate buffer $0.1 \mathrm{M}$, pH 5.0.

\subsection{Operating conditions}

Batch and fed-batch experiments were carried out in a 600$\mathrm{mL}$ stainless steel reactor (Parr 4563, Parr Instruments) at $30^{\circ} \mathrm{C}$ of temperature and $400 \mathrm{rpm}$ of stirring rate. Compressed air was continuously sparged into the culture medium at a flow-rate of $1 \mathrm{vvm}$ (measured at standard conditions of pressure and temperature). The operating pressure was set by the manipulation of the pressure of the inlet gas and the regulatory valve position in the exit gas line [18]. The values of air absolute pressure studied were 1.2 bar, 3 bar and 6 bar in batch cultures, and 1 bar, 6 bar and 12 bar in the fed-batch strategy. The reactor was equipped with a pressure transducer to monitor total internal pressure. Fed-batch experiments started-up in batch mode with $1 \mathrm{~g} \mathrm{~L}^{-1}$ of initial sucrose in a volume of $175 \mathrm{~mL}$. The initial yeast concentration was $15 \mathrm{~g} \mathrm{~L}^{-1}$. Feeding of a $100 \mathrm{gL}^{-1}$ sucrose media was started after $1 \mathrm{~h}$ of batch growth and performed at an increase flow rate (in order to keep dilution rate of $0.025 \mathrm{~h}^{-1}$ ) for about $40 \mathrm{~h}$.

\subsection{Analytical methods}

Cell concentration was estimated through optical density at a wavelength of $620 \mathrm{~nm}$, previously correlated to cell dry weight determination. Sucrose was measured by 3,5-dinitrosalicylic acid method [23] modified. Ethanol was quantified by HPLC (Jasco) with a Chrompack column and a RI detector (830-PU, Jasco). The eluent was $\mathrm{H}_{2} \mathrm{SO}_{4} 0.01 \mathrm{~N}$ at $0.7 \mathrm{~mL} \mathrm{~min}^{-1}$ and a column temperature of $40^{\circ} \mathrm{C}$.

\subsection{Image analysis}

Image acquisition was conducted in an optical microscope (Diaphot 300, Nikon Corp.) with $400 \times$ magnification coupled with a black and white camera (Sony CCD AVC D5CE) linked to a personal computer by a frame grabber (DT3155, Data Translation, Inc.). The images were focused in a way to enhance the cells contour. The original image was divided by its background, an image without cells, to remove irregularities. A median filter $(3 \times 3)$ was used in the resulting image before the binarization step. Afterwards, a step to suppress objects connected to image border and a holefill procedure [24] were performed. Application of morphological operations, like erosion (to remove small debris) and reconstruction, produced the final binary image. These image processing procedures were developed with Matlab v.6.1 (The Mathworks Inc.) package and were fully automated.

Feature extraction and object separation were necessary to classify "budding cells" (not separated) and "single" (individual well separated cells) cells and to determine their frequency in the analyzed samples. Initially, objects were labeled permitting to extract individual properties (area, equivalent diameter, major axis length, minor axis length, among others). Assuming that the cell projection onto the image is an ellipse, a parameter called "elongation" (major axis length/minor axis length) was computed according to Pons and Vivier $[22,25]$.

\subsection{Statistical analysis}

Comparison of mean values between different air pressure experiments was performed by Student' unpaired $t$ test. Values of $p<0.05$ were considered statistically significant.

\section{Results and discussion}

\subsection{Effect of pressure on yeast metabolism: batch operation}

Time course profiles of growth, ethanol production and sucrose consumption of $C$. utilis batch cultures are presented in Fig. 1. The raise of total air pressure from 1.2 bar to 6 bar led to an increase of 1.8 -fold in the final cell dry weight. Also, an improvement in biomass yield from 0.04 at 1.2 bar to 0.24 at 6 bar of air pressure was observed. That was probably due to the improvement of oxygen transfer rate from the air to the culture medium that is mainly achieved due to the increase of oxygen solubility with the increase of pressure [16], thus allowing the enhancement of cellular growth due to the prevention of oxygenlimited growth. Additionally, the biomass productivity was clearly enhanced with the rise of air pressure. After $12 \mathrm{~h}$ of yeast growth, values of productivity equals to $65 \mathrm{mg} \mathrm{L}^{-1} \mathrm{~h}^{-1}, 102 \mathrm{mg} \mathrm{L}^{-1} \mathrm{~h}^{-1}$ and $792 \mathrm{mg} \mathrm{L}^{-1} \mathrm{~h}^{-1}$ was attained respectively at 1.2 bar, 3 bar and 6 bar. Other non-conventional yeasts such as Kluyveromyces marxianus [26], Yarrowia lipolytica [27] and P. pastoris [18] were successfully cultivated under increased air pressure with significant improvements in final biomass concentration. However, for S. cerevisiae, yeast with respire-fermentative pathway, the increase of air pressure led to a decrease on biomass productivity for a batch mode of operation [19].

In the batch cultures of $C$. utilis, during the initial growth phase, cells consumed sucrose, which is metabolized oxidoreductively, producing biomass and ethanol. After that, ethanol produced was almost totally consumed by the cells. Moreover, the increase of total air pressure led to an earlier and completely consumption of ethanol. The raise of air pressure from 1.2 bar to 6 bar led to a significant decline on ethanol production. A 2.3-fold reduction of ethanol concentration was attained by increasing air pressure to 6 bar. This result indicated that the aeration of culture with air at 1 bar was insufficient to prevent oxygen limitation and a significant switch of the metabolism to the fermentative pathway was 

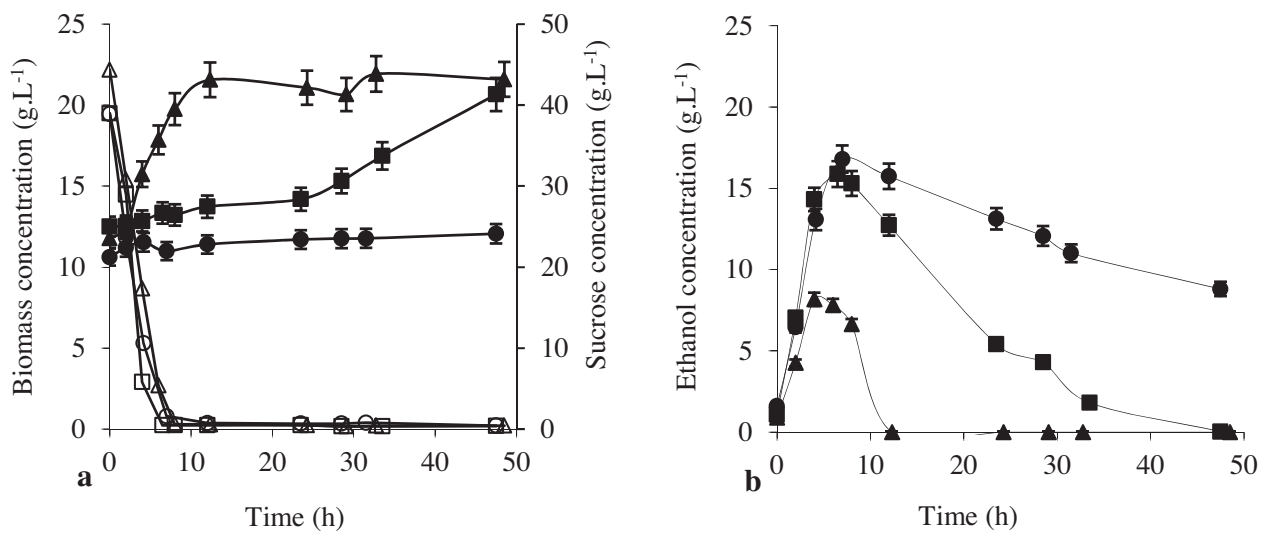

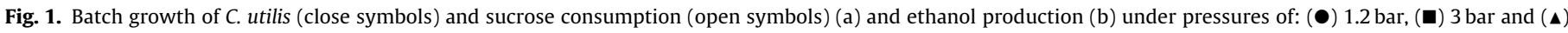
6 bar pressure. Data are the average and standard deviation of independent triplicates.

observed. However, the use of 6 bar air pressure allows yeast cells to keep using predominantly the oxidative metabolism.

\subsection{Effect of pressure on yeast metabolism: fed-batch operation}

As the results above demonstrated, the increase of air pressure up to 6 bar could be successfully applied for $C$. utilis batch growth, improving the final cell mass production and reducing the ethanol formation. Thus, fed-batch mode of operation was used to validate the results in this mode of operation, the most used to reach high cell density cultures.

Fig. 2 shows the effect of air pressure increase on biomass and ethanol production in fed-batch cultures. The sucrose concentration in the medium remained below $2 \mathrm{~g} \mathrm{~L}^{-1}$ for all pressures tested and no differences were observed in the substrate consumption behavior.

A clear enhancement in biomass production was observed with increased air pressure. The raise of total pressure from 1 bar to 12 bar led to approximately 1.5 -fold improvement in the final cell dry weight. Also, biomass productivity was enhanced by the increase of air pressure. The maximum productivity in the 12 bar air pressure experiment $\left(900 \mathrm{mg} \mathrm{L}^{-1} \mathrm{~h}^{-1}\right)$ was obtained $24 \mathrm{~h}$ after the beginning of the process and remained unchanged until the end. On the other hand, with 6 bar air pressure, a biomass productivity of $800 \mathrm{mg} \mathrm{L}^{-1} \mathrm{~h}^{-1}$ was reached at $30 \mathrm{~h}$, and this value dropped to half at the end of the experiment. Moreover, in the assay conducted at 1 bar, only $600 \mathrm{mg} \mathrm{L}^{-1} \mathrm{~h}^{-1}$ of productivity was attained.

The results in Fig. 2 show that air at 1 bar was not enough to ensure the oxygen cellular demand, since a higher ethanol and a lower cell concentration were obtained compared to experiments under 12 bar of air pressure. In fact, the ethanol production observed at 1 bar $\left(8 \mathrm{~g} \mathrm{~L}^{-1}\right)$ was totally reduced by the reactor pressurization up to 12 bar.

During the first $24 \mathrm{~h}$, cell behavior at 6 bar and 12 bar of air pressure was similar. However, after this period, for 6 bar air pressure, the cell concentration started to decrease. This result occurred at the same time when the ethanol concentration started to increase significantly. In this type of cell cultivation high cell densities are reached, thus a high capacity of oxygen supply of the system is required. This indicates that 6 bar air pressure rise, for the cell densities achieved in the fed-batch experiments was probably insufficient to prevent oxygen-limited cell growth and some sucrose fermentation occurred.

The results reported herein proved that the reactor pressurization up to 12 bar could be successfully applied to prevent by-products formation, such as ethanol, on C. utilis fed-batch cultivations. Since the preliminary reports of Páca and Grégr [28], who obtained an increase on C. utilis cell mass yield in batch cultures, by a 1.7 fold raise of oxygen partial pressure and Onken et al. [29], who observed a decrease in biomass yield in continuous cultures under 7 bar of air pressure, no further reports are known on the behavior of this yeast, particularly in fed-batch cultures under increased pressure. Other microorganisms have been more recently studied by Knabben et al. [30] that used increased pressure pilot-plant bioreactors to minimize overflow metabolism in E. coli fed-batch cultures. Also, Belo et al. [17] observed that the ethanol production was reduced by increasing air pressure from 1 bar to 10 bar in $S$. cerevisiae cultures.

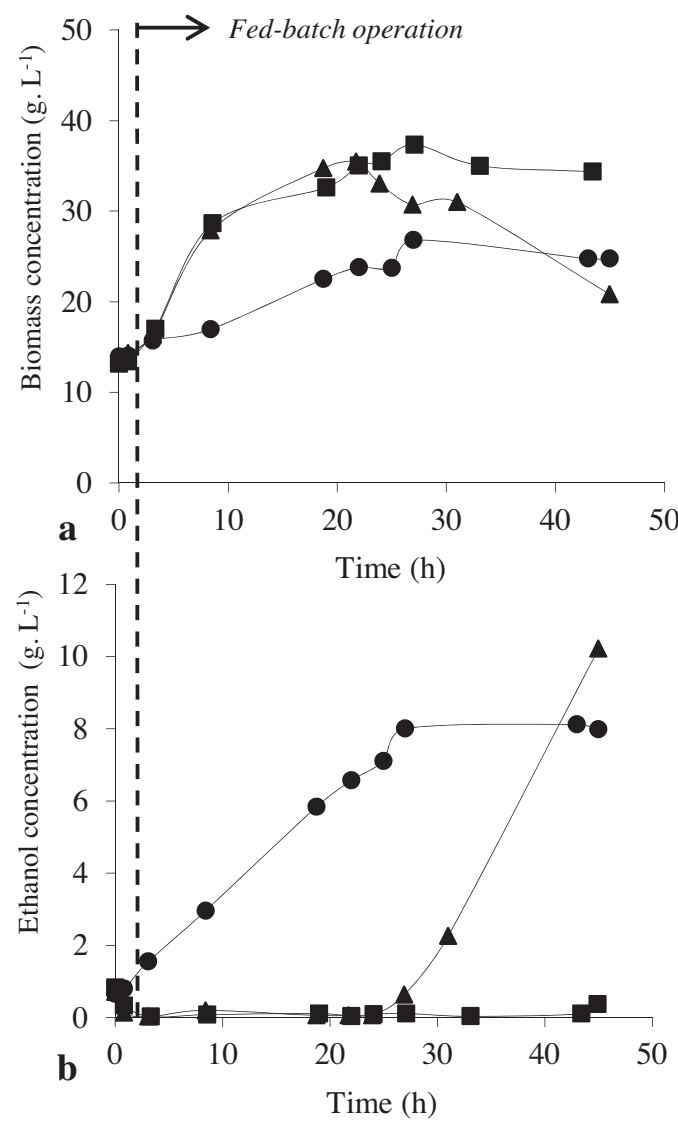

Fig. 2. Cell growth (a) and ethanol production (b) for Candida utilis CBS 621 during fed-batch experiments, under increased air pressures: $(\bullet) 1$ bar, ( $\boldsymbol{\Delta}) 6$ bar and $(\boldsymbol{\square})$ 12 bar, with a dilution rate of $0.025 \mathrm{~h}^{-1}$ and a feed medium with $100 \mathrm{~g} \mathrm{~L}^{-1}$ of sucrose. Data are the average and standard deviation of independent triplicates. 

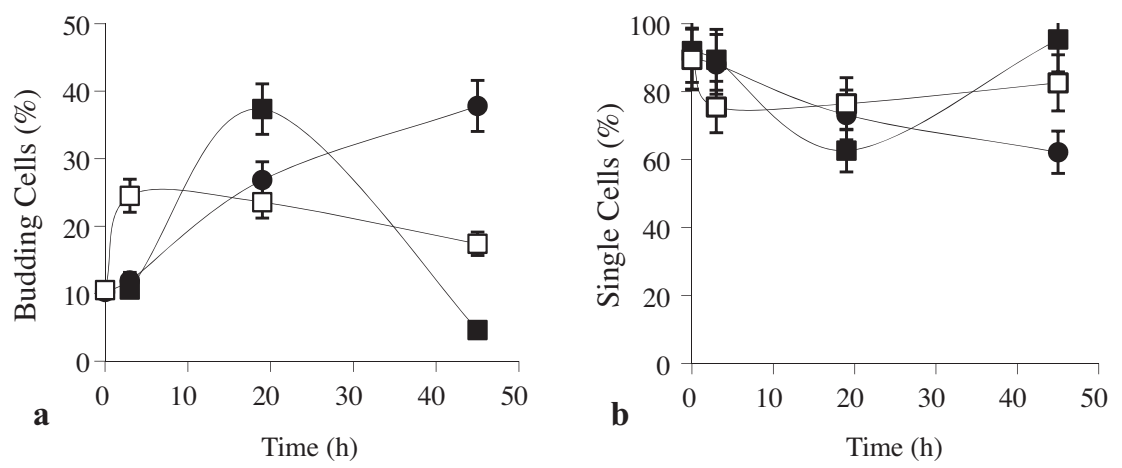

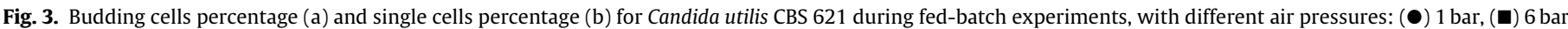

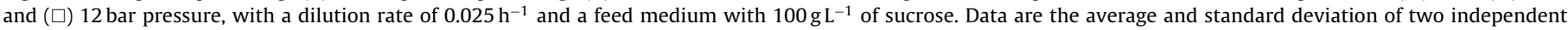
experiments.

\subsection{Effect of pressure on yeast morphology}

Growth rate, mutation, and environmental conditions affect yeast size and shape distributions, but, in general, the effect of spatial variations in large-scale bioreactors is not taken into account. Due to the differences observed in the residence time distribution in large reactors, cells are distinctly exposed to high pressures (at the bottom) and to low pressures (on top). As a consequence, analysis of pressure effects in cell morphology must be considered.

An image-processing tool accomplished the analysis of cell morphology under different fed-batch experimental conditions. In a first approach, cells were classified into single cells and budding cells. The composition of the cell aggregates varies with the growth phase, depending on whether it is the stationary or the exponential phase [31]. Zalewski and Buchholz [31] classified yeast cells of $S$. cerevisiae in four classes according to various forms they present along growth: small cells, budding cells (two cell gemmules, with the same size), single cells (with large vacuole), and dead cells (smaller cells). Likewise, the set of images captured for the same sample were treated and processed, yielding results for the percentage of single cells and budding cells (Fig. 3).

After $3 \mathrm{~h}$ of growth, a decrease was observed of single cell from $90 \%$ to about $70-80 \%$ whereas a slightly increase of budding cells percentage took place. According to Zalewski and Buchholz [31] and Pons and Vivier [25], a characteristic of good inoculate adaptation to the new culture is the rapid decrease in the amount of single cells in culture and the increase in the percentage of budding cells.

The percentage of budding cells on yeast culture growing at 1 bar increased until the end of the process, accomplished with a reduction of single cells percentage. On the other hand, in the experiments under 6 bar and 12 bar, the percentage of budding cells was increasing only during $20 \mathrm{~h}$, offsetting the decrease in the single cells percentage. However, after this period, there was an increase in single cells and a reduction of gemmules. This behavior can be explained by the different cell growth rates. The low number of budding cells observed in the experiment with 6 bar air pressure confirmed the cell growth limitation (Fig. 2).

Coelho et al. [22] observed that $S$. cerevisiae cell division was strongly affected by 5 bar $\mathrm{O}_{2}$ and 6 bar $\mathrm{CO}_{2}$ pressures, while nitrogen and air to a maximum of 6 bar pressure were innocuous to yeast. Belo et al. [21] reported that no differences were found between the genealogical age of cell populations (assessed by bud scars counting) under environments of air at 1 bar, 6 bar, $10 \mathrm{bar}$ and pure oxygen at 1.3 bar. However, an increase in the fraction of older cells was observed for the final cultures exposed to 15 bar of air pressure or 3.2 bar of $\mathrm{O}_{2}$ pressure.

The cell size distribution of yeast cells exposed to hyperbaric air is a useful tool to assess cellular viability, once considered non-viable cells are smaller than viable cells [32]. After $3 \mathrm{~h}$ of the beginning of growth, most yeast cells present an average area of approximately $30 \mu^{2}$ (Table 1). Moreover, it was not observed yeast cells with a projected area exceeding $70 \mu \mathrm{m}^{2}$ (data not shown). An increase in the average area at the end of growth, compared with its initial values, was obtained for all the pressures tested, which is in accordance with cell growth retardation at the stationary phase of growth [22].

In the stationary phase of growth $(43 \mathrm{~h})$, it was observed a slightly increase in projected area by rising the air pressure from 1 bar to 12 bar $(p<0.001)$. This was probably due to the increase on the percentage of older cells, which under normal conditions are bigger in size.

The effect of pressure on cell size is strongly dependent of the gas nature and yeast strain. For $S$. cerevisiae cultures, Coelho et al. [22] observed that the increased air pressure up to 6 bar did not significantly affect average cell size, while a decrease in the cell size distribution was found for cells exposed for $7.5 \mathrm{~h}$ to 6 bar $\mathrm{CO}_{2}$. Belo et al. [21] reported that air pressure increase up to 15 bar caused $S$. cerevisiae cells compression and an increase in the number of aged cells. Lopes et al. [33] found a $Y$. lipolytica cell size decrease for the 8 bar culture, compared to cell size obtained at 4 bar and at atmospheric pressure.

Yeast shape can be assessed by an elongation factor as a discriminatory parameter. Since it was assumed that the cell projection onto the image is an ellipse, the elongation factor was defined as the ratio between major axis length $\left(F_{\max }\right)$ and the minor axis length $\left(F_{\min }\right)$. In the first sample $(3 \mathrm{~h})$, the major percentage of cells has the same elongation parameter of approximately 1.6, and displayed a typical oval form in all the assays. The results demonstrated that cell exposure to increased air pressure did not induce yeast shape changes and cells remained oval under pressures up to 12 bar (Fig. 4).

Kawasse et al. [34] reported a $25 \%$ increase in the elongation factor when the $Y$. lipolytica cells were exposed to a thermal and oxidative stress. However, Lopes et al. [33] observed that $Y$. lipolytica cells remained oval under air pressure up to 8 bar. Dong et al. [35] observed that under atmospheric pressure cells were round and smooth, but when cultured at 5 bar, cells became more flat and wrinkles could be seen on the cell membranes. With the pressure increase up to $15 \mathrm{bar}$, more disrupted cell membrane structures and dead cells were observed. The results reported above allow the conclusion that air pressure did not inflict stress to the $C$. utilis cells, as the morphological analysis has proven since cells kept the predominant oval form and no decrease on average area was observed. 
Table 1

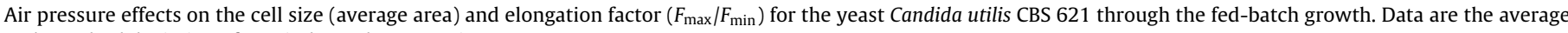
and standard deviation of two independent experiments.

\begin{tabular}{|c|c|c|c|c|c|c|}
\hline \multirow[t]{2}{*}{$P$ (bar) } & \multicolumn{3}{|l|}{$\begin{array}{l}\text { Cell size } \\
\text { Area }\left(\mu \mathrm{m}^{2}\right)\end{array}$} & \multicolumn{3}{|c|}{$\begin{array}{l}\text { Elongation factor } \\
F_{\max } / F_{\min }\end{array}$} \\
\hline & $3 \mathrm{~h}$ & $19 \mathrm{~h}$ & $43 \mathrm{~h}$ & $3 \mathrm{~h}$ & $19 \mathrm{~h}$ & $43 \mathrm{~h}$ \\
\hline 1 & $31.0 \pm 0.6$ & $24.7 \pm 3.4$ & $27.4 \pm 1.4$ & $1.59 \pm 0.02$ & $1.66 \pm 0.05$ & $1.26 \pm 0.02$ \\
\hline 6 & $29.6 \pm 0.8$ & $23.8 \pm 1.0$ & $34.5 \pm 0.2$ & $1.60 \pm 0.02$ & $1.83 \pm 0.02$ & $1.55 \pm 0.04$ \\
\hline 12 & $31.4 \pm 2.3$ & $25.1 \pm 0.3$ & $35.8 \pm 0.6$ & $1.64 \pm 0.03$ & $1.78 \pm 0.05$ & $1.67 \pm 0.04$ \\
\hline
\end{tabular}
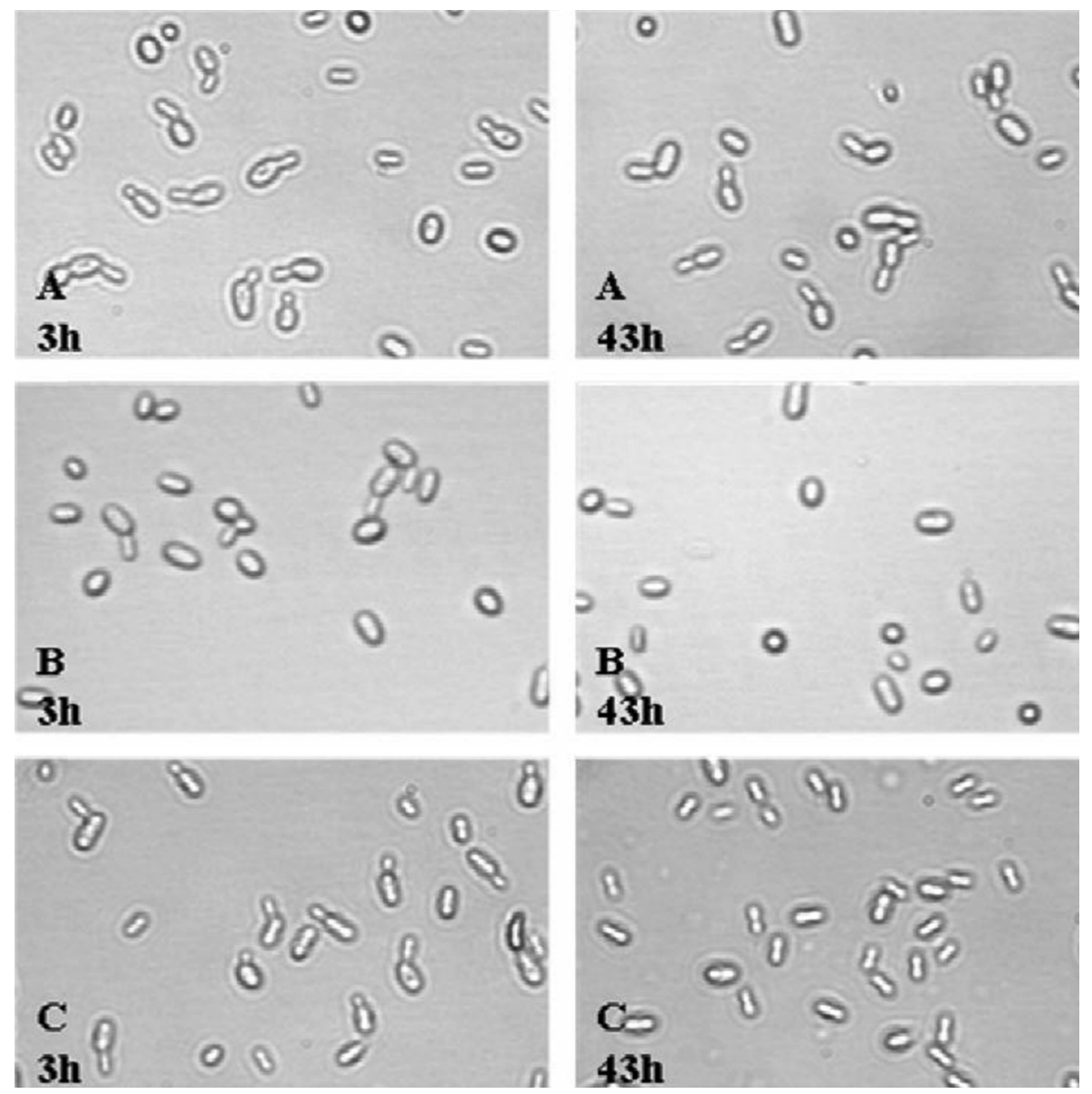

Fig. 4. Phase contrast microscope photographs (magnification $400 \times$ ) of C. utilis CBS 621 grown on fed-batch cultures at: (A) 1 bar, (B) 6 bar and (C) 12 bar.

\section{Conclusion}

High cell density cultivation of microorganisms are still limited by many factors such as substrate inhibition, oxygen transfer limitations, accumulation of cellular by-products and inhibition of cellular respiration.

The results reported herein proved that, for the experimental conditions used, an air pressure increase up to 6 bar and 12 bar can be successfully applied respectively, to the batch and fed-batch cultivation of $C$. utilis. Moreover, the increase of oxygen availability by the reactor pressurization allows yeast cells to remain predominantly in the oxidative pathway and prevents the ethanol formation.

In the present work, an automated image analysis procedure allowing discrimination between single and budding cells, as well as determination of cell shape and size under increased air pressure was employed. No significant differences in cell size and shape were observed in 12 bar air pressure cultures and yeast cells kept the typical oval form.
Our results suggest that hyperbaric air is an alternative strategy to improve $C$. utilis biomass production, reaching high cell densities in fed-batch process, without cellular damage, as proved by morphology analysis.

\section{Acknowledgement}

The authors acknowledge the financial support provided by "Fundação para a Ciência e Tecnologia", Portugal.

\section{References}

[1] van den Broek PJA, van Gompel AE, Luttik MAH, Pronk JT, van Leeuwen CCM. Mechanism of glucose and maltose transport in plasma-membrane vesicles from the yeast Candida utilis. Biochem J 1997;321:487-95.

[2] Bekatorou A, Psarianos C, Koutinas AA. Production of food grade yeasts. Food Technol Biotechnol 2006;44:407-15.

[3] Ghoul M, Boudrant J, Engasser JM. A comparison of different techniques for the control of the growth of Candida utilis CBS 621. Process Biochem $1991 ; 26: 135-42$. 
[4] Moftah OAS, Grbavčić S, Žuža M, Luković N, Bezbradica D, Knežević-Jugović Z. Adding value to the oil cake as a waste from oil processing industry: production of lipase and protease by Candida utilis in solid state fermentation. Appl Biochem Biotechnol 2012:166:348-64.

[5] van Urk H, Bruinenberg PM, Veenhuis M, Scheffers WA, van Dijken JP. Respiratory capacities of mitochondria of Saccharomyces cerevisiae CBS 8066 and Candida utilis CBS 621 grown under glucose limitation. Antonie Van Leeuwenhoek 1989;56:211-20.

[6] Boze H, Moulin G, Galzy P. Production of food and fodder yeasts. Crit Rev Biotechnol 1992;12(1/2):65-86

[7] Lee B-K, Kim JK. Production of Candida utilis biomass on molasses in different culture types. Aquacult Eng 2001;25(2):111-24.

[8] Kunigo M, Buerth C, Tielker D, Ernst JF. Heterologous protein secretion by Candida utilis. Appl Microbiol Biotechnol 2013;97:7357-68.

[9] Wei W, Hong-Lan Y, Huifang B, Daoyuan Z, Qi-Mu-Ge S, Wood AJ. The effective expression of xylanase gene in Candida utilis by $18 \mathrm{~S}$ rDNA targeted homologous recombination in pGLR9K. Mol Biol Rep 2010;37:2615-20.

[10] Hong YR, Chen YL, Farh L, Yang WJ, Liao CH, Shiuan D. Recombinant Candida utilis for the production of biotin. Appl Microbiol Biotechnol 2006;71:211-21.

[11] Ikushima S, Fujii T, Kobayashi O, Yoshida S, Yoshida A. Genetic engineering of Candida utilis yeast for efficient production of L-lactic acid. Biosci Biotechnol Biochem 2009;73:1818-24.

[12] Tamakawa H, Ikushima S, Yoshida S. Efficient production of L-lactic acid from xylose by a recombinant Candida utilis strain. J Biosci Bioeng 2010;113:73-5.

[13] Ordaz L, López R, Melchy O, de la Torre M. Effect of high-cell-density fermentation of Candida utilis on kinetic parameters and the shift to respiro-fermentative metabolism. Appl Microbiol Biotechnol 2001;57:374-8.

[14] Yee L, Blanch HW. Recombinant protein expression in high cell density fedbatch cultures of Escherichia coli. Biotechnology 1992;10:1550-6.

[15] de la Torre M, Flores LB, Chong E. High cell density yeast production: process synthesis and scale-up. In: Galindo E, Ramírez OT, editors. Advances in bioprocess engineering. Amsterdam: Kluwer; 1994. p. 67-74.

[16] Lopes M, Mota M, Belo I. Oxygen mass transfer rate in a pressurized lab-scale stirred bioreactor. Chem Eng Technol 2013;36(10):1779-84.

[17] Belo I, Pinheiro R, Mota M. Fed-batch cultivation of Saccharomyces cerevisiae in a hyperbaric bioreactor. Biotechnol Prog 2003;19:665-71.

[18] Lopes M, Belo I, Mota M. Batch and fed-batch growth of Pichia pastoris under increased air pressure. Bioprocess Biosyst Eng 2013;36:1267-75

[19] Pinheiro R. Belo I, Mota M. Physiological behavior of Saccharomyces cerevisiae under increased air and oxygen pressures. Biotechnol Lett 1997;19:703-8.

[20] Pinheiro R, Belo I, Mota M. Oxidative stress response of Kluyveromyces marxianus to hydrogen peroxide, paraquat and pressure. Appl Microbiol Biotechnol 2002:58:842-7.
[21] Belo I, Pinheiro R, Mota M. Morphological and physiological changes in Saccharomyces cerevisiae by oxidative stress from hyperbaric air. J Biotechnol 2005; 115:397-404.

[22] Coelho MAZ, Belo I, Pinheiro R, Amaral AL, Mota M, Coutinho JAP, et al. Effect of hyperbaric stress on yeast morphology: study by automated image analysis. Appl Microbiol Biotechnol 2004;66:318-24.

[23] Miller GL. Use of dinitrosalicylic acid reagent for determination of reducing sugar. Anal Chem 1959;31:426-8.

[24] Russ JC. The image processing handbook. Boca Raton: CRC Press; 2002.

[25] Pons M-N, Vivier H. Morphometry of yeast. In: Wilkinson MHF, Schut F, editors Digital image analysis of microbes: imaging, morphometry, fluorometry and motility techniques and applications. London: John Wiley \& Sons Ltd.; 1998. p. 199-224.

[26] Pinheiro R, Belo I, Mota M. Air pressure effects on biomass yield of two different Kluyveromyces strains. Enzyme Microb Technol 2000;26:75662.

[27] Lopes M, Gomes N, Mota M, Belo I. Yarrowia lipolytica growth under increased air pressure: influence on enzyme production. Appl Biochem Biotechnol 2009; 159:46-53.

[28] Páca J. Grégr V. Effect of PO2 on growth and physiological characteristics of Candida utilis in a multistage tower fermentor. Biotechnol Bioeng 1979;21:1827-43.

[29] Onken U, Kiese S, Jostmann Th. An airlift fermenter for continuous cultures at elevated pressures. Biotechnol Lett 1984;6(5):283-8.

[30] Knabben I, Regestein L, Marquering F, Steinbusch S, Lara AR, Büchs J. High celldensity processes in batch mode of a genetically engineered Escherichia col strain with minimized overflow metabolism using a pressurized bioreactor. J Biotechnol 2010;150:73-9.

[31] Zalewski K, Buchholz R. Morphological analysis of yeast cells using an automated image processing system. J Biotechnol 1996;48:43-9.

[32] Thomas CR, Paul GC. Applications of image analysis in cell technology. Curr Opin Biotechnol 1996;7:35-45.

[33] Lopes M, Gomes N, Gonçalves C, Coelho MAZ, Mota M, Belo I. Yarrowia lipolytica lipase production enhanced by increased air pressure. Lett Appl Microbiol 2008:46:255-60.

[34] Kawasse FM, Amaral PF, Rocha-Leão MHM, Amaral AL, Ferreira EC, Coelho MAZ. Morphological analysis of Yarrowia lipolytica under stress conditions through image processing. Bioprocess Biosyst Eng 2003;25:371-5.

[35] Dong Y, Yang Q Jia S, Qiao C. Effects of high pressure on the accumulation of trehalose and glutathione in the Saccharomyces cerevisiae cells. Biochem Eng J 2007;37:226-30. 